\title{
WYKORZYSTANIE METODY QFD DLA WSPARCIA ZARZĄDZANIA WIEDZĄ W PLANOWANIU PROCESÓW INNOWACJI
}

\author{
Magdalena Jurczyk-Bunkowska \\ Politechnika Opolska, Instytut Innowacyjności Procesów i Produktów \\ Przemysław Polak \\ Szkoła Główna Handlowa w Warszawie, Instytut Informatyki i Gospodarki Cyfrowej
}

\begin{abstract}
Streszczenie: W artykule zaproponowano wykorzystanie diagramu macierzy QFD do jednego z etapów planowania procesu innowacji. Celem takiego podejścia jest wsparcie zarządzania wiedzą, a dokładnie - skodyfikowanie wiedzy ukrytej. Procesy innowacji zazwyczaj są realizowane przez multidyscyplinarne zespoły, w których uzgodnienia często bywają problematyczne ze względu na trudności komunikacyjne. Na przykładzie wyboru innowacyjnego rozwiązania $\mathrm{w}$ przedsiębiorstwie produkcyjnym pokazano, w jakim stopniu wykorzystanie diagramu metody QFD wspomaga dzielenie się wiedzą w celu podjęcia decyzji związanej z planowaniem celu procesu innowacji.
\end{abstract}

Slowa kluczowe: zarządzanie innowacjami, planowanie, metoda QFD, zarządzanie wiedzą

DOI: $10.17512 /$ znpcz.2016.3.1.02

\section{Wprowadzenie}

Właściwe wykorzystanie wiedzy jest kluczowym czynnikiem przewagi konkurencyjnej uzyskiwanej przez współczesne organizacje. Decyduje on o odpowiedniej alokacji zasobów i umiejętności wykorzystania prawidłowo zidentyfikowanych szans. By osiągnąc taki efekt, należy odpowiednio zarządzać wiedzą. Ten aspekt podkreśla definicja mówiąca, że zarządzanie wiedzą jest procesem wykorzystania kapitału intelektualnego do uzyskania przewagi konkurencyjnej (Schermerhorn 2008, s. 56). Pojęcie to jest jednak bardzo obszerne i stąd bywa precyzowane ze względu na różne cele, np. z punktu widzenia systemów informacyjnych, zarząazzania zasobami ludzkimi czy kształtowania strategii organizacji. Profesor Perechuda, sprzeciwiając się definiowaniu tego pojęcia, argumentuje, że jest ono bardzo pojemne i obejmuje zasadniczo wszystko, ponieważ wiedza oznacza myśl, czyli byt niematerialny, z którego - według kosmogonii - powstaje wszechświat (Perechuda 2005, s. 25). Niemniej na pewno można wskazać główne zadania zarządzania wiedzą, którymi są (Kisielnicki 2004):

- wykorzystanie posiadanych w organizacji zasobów wiedzy,

- poszukiwanie i absorbowanie zewnętrznych zasobów wiedzy,

- stworzenie takich warunków, aby wszyscy uczestnicy procesu decyzyjnego czuli się zobowiązani do dzielenia się posiadanymi zasobami wiedzy i jej kreowaniem. 
Realizacja tych zadań dotyczy również zarządzania procesami innowacji, które obejmują wszystkie działania związane z kreowaniem pomysłu, powstaniem wynalazku, a następnie wdrożeniem nowego produktu lub procesu (Pomykalski 2001). Specyfika tych procesów została opisana dzięki szerokim badaniom pod nazwą MIRP (Minnesota Innovation Research Program) (Schroeder i in. 1986, s. 501523). Pojawiło się stwierdzenie, że składają się na nie zbieżne i rozbieżne działania, które mogą powtórzyć się w czasie oraz na różnych płaszczyznach organizacyjnych. Działania realizowane w ramach procesów innowacji w bardzo szerokim ujęciu można określić jako tworzenie, gromadzenie i wdrażanie nowej wiedzy w praktykę funkcjonowania organizacji. $Z$ tego względu zasadnym jest poszukiwanie i wdrażanie narzędzi wspomagających dyfuzję wiedzy w kolejnych fazach procesu. W ten nurt poszukiwania wpisuje się niniejszy artykuł, którego celem jest pokazanie, w jaki sposób metoda QFD (ang. Quality Function Deployment) może wspierać dzielenie się wiedzą i w efekcie wpływać na jej wzrost w obszarze zarządzania procesami innowacji. Zademonstrowano to na przykładzie planowania innowacji $\mathrm{w}$ systemie produkcyjnym przedsiębiorstwa wytwarzającego meble na indywidualne zamówienia klientów. Metodą badawczą, którą zastosowano, było studium przypadku bazujące na współuczestnictwie w procesie podejmowania decyzji, która dotyczyła wyboru jednego z wariantów innowacyjnych rozwiązań. $\mathrm{W}$ artykule omówiono zagadnienia związane $\mathrm{z}$ zarządzaniem wiedzą $\mathrm{w}$ planowaniu procesów innowacji, a szczególnie problemy niepewności, dzielenia się wiedzą ukrytą oraz wyrównywania poziomów wiedzy. Wskazano cechy metody QFD, jako podejścia wspomagającego zarządzanie wiedzą w różnych obszarach. Zaprezentowano zastosowanie w praktyce macierzy metody QFD dla wsparcia decyzji o wyborze innowacji na podstawie studium przypadku. Następnie szeroko przeanalizowano bezpośrednie i pośrednie efekty wykorzystania takiego podejścia. W podsumowaniu wskazano na korzyści wykorzystania metody QFD we wsparciu początkowych faz planowania procesu innowacji.

\section{Zarządzanie wiedzą w planowaniu procesów innowacji}

W znaczeniu funkcjonalnym zarządzanie wiedzą kompleksowo powinno obejmować realizację cyklicznych i ciągłych funkcji zarządzania, skoncentrowanych na zasobach spersonalizowanej, skodyfikowanej i ugruntowanej wiedzy oraz procesach $\mathrm{z}$ ich udziałem, a także warunkach realizacji przebiegu tych procesów w sposób umożliwiający osiąganie celów organizacji (Mikuła 2011, s. 18). Najważniejszym dla przedsiębiorstwa celem realizacji procesów innowacji, bez względu na ich poziom nowatorstwa, jest podnoszenie własnej konkurencyjności. Niestety, jedną z najbardziej charakterystycznych cech procesów innowacji jest towarzysząca im niepewność. Definiuje się ją jako lukę pomiędzy posiadanymi informacjami a tymi, które są potrzebne do wykonania określonego zadania (Galbraith 1977). Jest to bardzo niewygodne dla zarządzających, ponieważ woleliby oni mieć możliwość podejmowania decyzji w oparciu o twarde analizy. Niestety, brak wiedzy o czynnikach kształtujących proces innowacji utrudnia zastosowanie tego typu narzędzi, które są z powodzeniem wyko- 
rzystywane m.in. w zarządzaniu projektami. Niepewność w procesach innowacji dotyczy między innymi (Jurczyk-Bunkowska 2015):

- ostatecznego efektu realizacji poszczególnych działań (często o charakterze eksperymentalnym), co ogranicza precyzyjne określenie końcowego efektu jego realizacji;

- liczby i rodzaju działań, które w ramach procesu będą musiały zostać podjęte;

- struktury procesu wynikającej z relacji między działaniami, ich następstwa i liczby powtórzeń;

- liczby współuczestników procesu innowacji i zależności pomiędzy nimi.

W tym kontekście widać potrzebę poszukiwania narzędzi wspomagających pozyskiwanie, rozwijanie, kodyfikowanie oraz transfer i wykorzystanie wiedzy, w tym szczególnie wiedzy ukrytej w organizacji. Jest to uzasadnione w odniesieniu do każdego etapu planowania procesu innowacji, jednak chyba najbardziej pożądane w sytuacji określania jego celu, który determinuje wszystkie pozostałe decyzje.

Istotą procesów innowacji jest tworzenie i wdrażanie nowej wiedzy. Mają one zatem oczywisty i bardzo silny związek z zarządzaniem wiedzą. Podstawą kreowania nowej wiedzy jest jej transfer, na co bardzo wyraźnie wskazuje japoński pięciofazowy model procesu organizacyjnego tworzenia wiedzy (Nonaka, Takeuchi 2000). Wyróżnione w nim fazy to:

1. Dzielenie się wiedzą ukrytą.

2. Szukanie pomysłów.

3. Potwierdzanie pomysłów.

4. Budowanie wzorca.

5. Wyrównywanie poziomów wiedzy.

Model ten opisuje zespół działań, których efektem jest upowszechnienie wiedzy, i można go odnieść również do planowania procesu innowacji, a szczególnie określania celu jego realizacji. Decyzje w tym zakresie są podejmowane w wyniku transformacji danych wejściowych, które bardzo często występują w postaci wiedzy ukrytej. Zebranie tej wiedzy wymaga zatem odpowiednich struktur i powinno być wspomagane adekwatnymi analizami. Prowadzi to w efekcie do wyrównywania poziomu wiedzy pomiędzy członkami zespołu realizującego proces innowacji.

W niniejszym artykule pokazano, w jaki sposób można wykorzystać powszechnie znane i szeroko stosowane narzędzie, jakim jest dom jakości (ang. House of Quality), czyli diagram wykorzystywany w metodzie QFD do wsparcia decyzji dotyczącej określenia celu procesu innowacji. Może zostać on wykorzystany jako narzędzie wymiany wiedzy ukrytej pomiędzy różnymi działami funkcjonalnymi przedsiębiorstwa i tym samym wspierać komunikację pomiędzy nimi. Stanowi zatem płaszczyznę budowania uzgodnień pomiędzy często rozbieżnymi wizjami realizacji celów strategicznych organizacji. Siłą tego narzędzia, oprócz jego powszechnej znajomości, jest skonkretyzowanie i powiązanie zależności pomiędzy określonymi rozwiązaniami technicznymi a ich efektami uwarunkowanymi oczekiwaniami klientów. 


\section{Zakres wykorzystania metody QFD}

QFD (ang. Quality Function Deployment) thumaczone jest w języku polskim jako „rozwinięcie funkcji jakości”. Metoda ta została po raz pierwszy zastosowana w latach sześćdziesiątych dwudziestego wieku i w swej pierwotnej wersji służy przełożeniu wymagań klientów na określone cechy produktu (Shahin 2008, s. 47-79). Wymagania te następnie opisuje się w postaci parametrów jego komponentów, aż ostatecznie określa się na tej podstawie parametry procesu produkcyjnego. Etapy te pokazano na Rysunku 1.

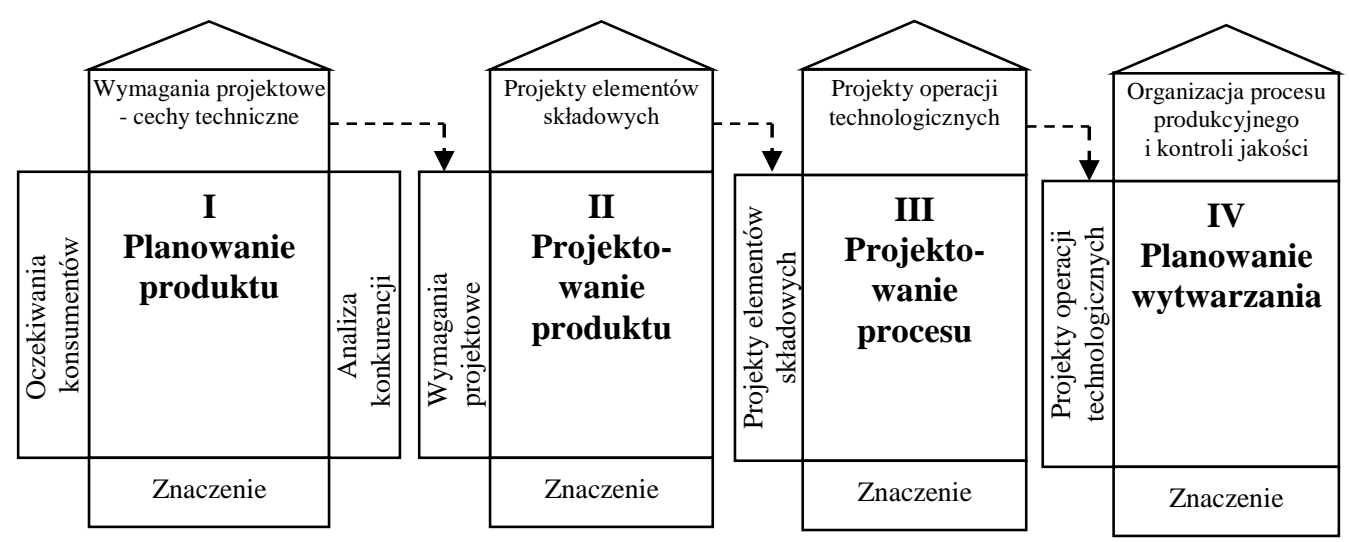

\section{Rysunek 1. Podstawowe etapy metody QFD}

Źródło: Opracowanie własne na podstawie (Cohen 1995)

Istotą metody QFD jest to, że uzależnia wartość parametrów technicznych produktów od wymagań klientów opisanych naturalnym dla nich językiem. Tym samym stanowi narzędzie przełożenia informacji pochodzących $\mathrm{z}$ rynku na cechy techniczne produktu. Dzięki temu staje się płaszczyzną do wymiany wiedzy pomiędzy konstruktorami a osobami odpowiedzialnymi za obsługę klienta. Ta wymiana wiedzy ma prowadzić do powstania produktów odpowiadających wymaganiom odbiorców. Podstawowym narzędziem metody jest tzw. dom jakości (ang. House of Quality), czyli macierz, która łączy potrzeby klienta, ich ważność wymagania techniczne i wzajemne powiązania pomiędzy nimi. Specjalnie zdefiniowane pola domu jakości nie są obligatoryjne i mogą zależeć od charakteru i złożoności zadania (Kudryavtsev, Grigoriev, Koryshev 2014, s. 118-127). W przedstawionym przykładzie, dla potrzeb wykorzystania domu jakości w planowaniu celu innowacji, zmodyfikowano matrycę. Ze względu na odmienne ryzyko towarzyszące wdrożeniu określonych rozwiązań o charakterze innowacji wprowadzono do niej ocenę jego stopnia ryzyka. Ma ona umożliwiać uwzględnienie w decyzji luki wiedzy, którą przedsiębiorstwo musi uzupełnić, by dane rozwiązanie wprowadzić. Im mniejsza jest luka wiedzy, tym większa szansa powodzenia we wdrożeniu danego rozwiązania. $Z$ dużą luką wiedzy wiąże się natomiast wysokie ryzyko niepowodze- 
nia wynikające np. z niemożności wytworzenia, pozyskania bądź wdrożenia brakującej wiedzy.

\section{Przykład wykorzystania metody QFD w planowaniu procesów innowacji}

Niniejszy punkt przedstawia sytuację wyboru innowacji w małym przedsiębiorstwie zajmującym się produkcją mebli na zamówienie klienta. Jest to rodzinna firma, zatrudniająca 16 pracowników produkcyjnych, którą zarządzają solidarnie dwaj bracia i ojciec. Dwa lata temu podjęto decyzję o znacznym rozwoju potencjału wytwórczego poprzez przeniesienie działalności do nowo wybudowanej hali produkcyjnej wyposażonej w wysokiej klasy maszyny. Mimo znacznych nakładów dało to oczekiwany efekt w postaci zmiany profilu działalności. Wprowadzenie nowego standardu obsługi pozwoliło na znaczne rozszerzenie rynku, a wytwarzane meble można zaliczyć do klasy ekskluzywnych. Zatrudniono pracowników produkcyjnych oraz monterów, podjęto też współpracę z lokalnymi firmami na różnych rynkach docelowych. W chwili obecnej firma realizuje projekty w Polsce i za granicą. Brała udział w targach w Mediolanie „EuroCucina 2016”, gdzie prezentowała swoje aranżacje, pozyskując kolejnych klientów. Mimo wspólnego zarządzania, zadania w przedsiębiorstwie są podzielone. Jeden z zarządzających zajmuje się projektowaniem konstrukcji i technologii, drugi planowaniem zleceń i zaopatrzeniem, natomiast trzeci, pierwszy właściciel firmy, nadzorem nad produkcją. Są oni wspomagani przez czterech pracowników biurowych realizujących zadania związane $\mathrm{z}$ marketingiem i finansami. Firma widzi szansę dalszej ekspansji poprzez ciągły rozwój. Działając w tym kierunku, analizowała wdrożenie nowych rozwiązań w systemie produkcyjnym. W pewnym momencie pojawiła się konieczność decyzji polegającej na wyborze jednej z kilku propozycji możliwych do wdrożenia:

1. Zakup systemu informatycznego pozwalającego tworzyć wizualizację prototypów mebli w wirtualnym środowisku.

2. Opracowanie systemu doradczego, bazującego na sztucznej inteligencji, wspomagającego wycenę zleceń, uwzględniającą nakład prac ręcznych oraz zamienniki.

3. Reorganizacja zaopatrzenia poprzez rezygnację z wielu dostawców, skoncentrowanie się na jednym $\mathrm{w}$ ramach określonej grupy asortymentowej i wdrożenie systemu B2B, pozwalającego na usprawnienie procesu.

4. Reorganizacja procesu nadzorowania produkcji i wdrożenie zarządzania przez projekt, w którym lider zespołu miałby być odpowiedzialny za realizację zlecenia od momentu pomiaru, poprzez projekt, aż po montaż ostateczny u klienta.

5. Wdrożenie systemu klasy ERP (ang. Enterprise Resource Planning).

6. Nawiązanie kooperacji z zewnętrzną firmą zajmującą się wyłącznie projektowaniem mebli i outsourcing tej fazy procesu produkcyjnego.

Każda $\mathrm{z}$ wymienionych propozycji prowadzi do innych efektów w odniesieniu do spełnienia warunków klientów, które determinują wzrost konkurencyjności. Rozwiązania charakteryzuje też różny poziom nowatorstwa. Chociaż każdy 
z wariantów można nazwać innowacją, ponieważ wiąże się z koniecznością wdrożenia nowej wiedzy z punktu widzenia przedsiębiorstwa, to jednak luka wiedzy jest różna, co determinuje różny poziom ryzyka. Rozwiązania wymagają też odmiennej wielkości nakładów finansowych. Uzgodnienie priorytetów w przypadku takiej decyzji niesie za sobą możliwość pojawienia się poważnych konfliktów. Ograniczone zasoby czasowe i finansowe uniemożliwiają też rozwijanie wszystkich koncepcji. W takich przypadkach proponuje się wykorzystać narzędzie, jakim jest zmodyfikowana macierz metody QFD. Pozwala ona na wymianę wiedzy pomiędzy różnymi działami funkcjonalnymi przedsiębiorstwa i ustalenie na tej podstawie planu, a dokładnie określenie celu prac nad rozwojem systemu produkcyjnego poprzez wdrożenie innowacji. Najważniejszą kwestią z punktu widzenia całego systemu i wszystkich zarządzających przedsiębiorstwem jest podniesienie konkurencyjności. Najpewniejszą drogą do tego jest zaspokojenie potrzeb klienta. W przypadku omawianej firmy jako główne elementy konkurencyjności wskazano:

- funkcjonalny oraz efektowny wizualnie i oryginalny projekt (wzornictwo);

- terminowość realizacji zlecenia;

- konkurencyjność cenową, bazującą na prawidłowo rozpoznanym koszcie realizacji projektu;

- możliwość współuczestniczenia przez klienta w projektowaniu mebli;

- krótki czas realizacji zlecenia.

\begin{tabular}{|c|c|c|c|c|c|c|c|c|c|}
\hline & 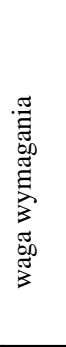 & 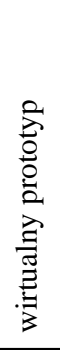 & 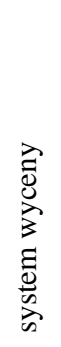 & 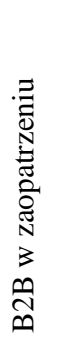 & 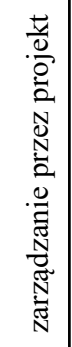 & 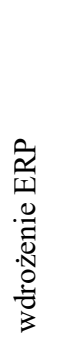 & 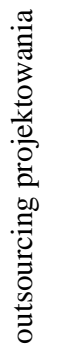 & $\begin{array}{l}\text { konkt } \\
\text { z poz }\end{array}$ & yina \\
\hline stylistyka projektu & 0,3 & 3,0 & & & & & 7,0 & + & -- \\
\hline terminowość realizacji zlecenia & 0,2 & & & 7,0 & 7,0 & 3,0 & & + & + \\
\hline koszt realizacji & 0,3 & & 7,0 & 3,0 & 3,0 & 3,0 & & - & + \\
\hline partycypacja w projektowaniu & 0,1 & 7,0 & 7,0 & & & & 3,0 & 0 & - \\
\hline krótki czas realizacji & 0,1 & & & 7,0 & 1,0 & 1,0 & & 0 & + \\
\hline \multicolumn{2}{|l|}{ znaczenie innowacji } & 1,6 & 2,8 & 3,0 & 2,4 & 1,3 & 2,4 & \multirow{3}{*}{\multicolumn{2}{|c|}{$\begin{array}{l}\text { legenda porównania: } \\
\text { ++ znaccna przewaga } \\
\text { +przewaga } \\
\text { 0 podobnie } \\
\text { - gorzzj } \\
-- \text { znacznie gorzej }\end{array}$}} \\
\hline \multicolumn{2}{|l|}{ stopień ryzyka (skala 1-5) } & 3,0 & 3,0 & 2,0 & 4,0 & 2,0 & 2,0 & & \\
\hline \multicolumn{2}{|l|}{$\begin{array}{l}\text { ocena innowacji } \\
\text { względem stopnia ryzyka }\end{array}$} & 0,5 & 0,9 & 1,5 & 0,6 & 0,6 & 1,2 & & \\
\hline
\end{tabular}


Rysunek 2. Diagram metody QFD wykorzystany do oceny innowacyjnych rozwiązań w systemie produkcyjnym

Źródło: Opracowanie własne

$\mathrm{Na}$ Rysunku 2 pokazano macierz QFD dla analizowanego przypadku. W obszarze określenia ważności wymagań klientów posłużono się opinią samych zarządzających przedsiębiorstwem. Podobnie postąpiono przy wypełnieniu obszaru zależności pomiędzy wymaganiami klientów a innowacyjnymi rozwiązaniami możliwymi do wdrożenia $\mathrm{w}$ systemie produkcyjnym. W modyfikacji macierzy QFD zaproponowano określenie skali ryzyka towarzyszącej każdemu $\mathrm{z}$ analizowanych rozwiązań. Jest ono tym wyższe, im większą lukę wiedzy trzeba uzupełnić, by wdrożyć określoną innowację w firmie.

Rozwiązania w analizowanym przykładzie można sklasyfikować jako innowacje o charakterze imitacji, np. wdrożenie ERP, wdrożenie B2B w zaopatrzeniu oraz rzeczywiste innowacje, np. opracowanie systemu wspomagającego wycenę zleceń. W przypadku pierwszej kategorii innowacji z otoczenia przedsiębiorstwa można pozyskać wiedzę niezbędną dla jej wdrożenia. W przypadku rzeczywistych innowacji wiedza ta musi zostać opracowana w samym przedsiębiorstwie lub na jego zlecenie w organizacji zewnętrznej, takiej jak np. uczelnia. Niesie to z sobą większe niż w przypadku innowacji o charakterze imitacji ryzyko niepowodzenia. Ponadto taki projekt będzie wiązał się z wyższymi nakładami finansowymi oraz koniecznością większego zaangażowania zarządzających $w$ jego wdrożenie, wszystkie te elementy należy uwzględnić przy ocenie rozwiązań. $Z$ tego względu wprowadzono ocenę innowacji, względem stopnia ryzyka, jako iloraz znaczenia innowacji i stopnia ryzyka określonego w skali od 1 , dla najmniejszego stopnia ryzyka, do 5, dla rozwiązania o największym stopniu ryzyka. Z analizy macierzy QFD pokazanej na Rysunku 2 wynika, że największe znaczenie dla realizacji strategii przedsiębiorstwa będzie miało wdrożenie rozwiązania $\mathrm{B} 2 \mathrm{~B} \mathrm{w}$ odniesieniu do zaopatrzenia. Powinno ono silnie wpłynąć na terminowość realizacji zleceń, ponieważ obecna współpraca z wieloma dostawcami tych samych pozycji asortymentowych tylko pozornie pozwala redukować koszty. Wdrożenie tego rozwiązania powinno też skrócić realizację zlecenia, ponieważ składanie i monitorowanie stanu zaawansowania dostaw oraz rozliczeń finansowych jest bardzo czasochłonne. Wybrany wariant może również wzmacniać wprowadzanie w późniejszych okresach rozwiązań takich jak wdrożenie systemu ERP czy zarządzania przez projekt. Dodatkowo rozwiązanie to cechuje się niewielkim poziomem ryzyka i dlatego zostało ostatecznie rekomendowane. Najważniejszym efektem zastosowania matrycy QFD był jednak nie sam wybór rozwiązania, ale doprowadzenie do uzgodnień opartych na obrazie wpływu poszczególnych rozwiązań na efekty dla przedsiębiorstwa.

\section{Analiza wsparcia zarządzania wiedzą w planowaniu procesów innowacji poprzez wykorzystanie diagramu metody QFD}


Istotą zarządzania wiedzą jest niwelacja luki wiedzy rozumianej jako różnica między posiadanymi zasobami wiedzy a wiedzą potrzebną dla podejmowania decyzji. Jak zauważają Suttonm i Pfeffer, w praktyce istnieje duża rozbieżność między posiadaną wiedzą a umiejętnością jej zastosowań (Suttonm, Pleffer 2002). Tę różnicę w odniesieniu do działania wchodzącego w skład planowania procesów innowacji wypełnić może wykorzystanie metody QFD. Zaproponowane podejście ma wspierać procesy komunikowania się, $\mathrm{w}$ trakcie których następują straty wiedzy tym większe, im więcej szczebli pośrednich między nadawcą a odbiorcą. Jak zauważano, zastosowanie proponowanego rozwiązania wspiera też procesy uczenia się na poziomie organizacji poprzez gromadzenie informacji, ich selekcję oraz dystrybucję. Gromadzenie i kodyfikowanie informacji wspiera również rozwijanie wiedzy w przedsiębiorstwie, ponieważ w wyniku procesów myślowych przekształcane są one w nową wiedzę, prowadząc tym samym do skuteczniejszego realizowania działań, w tym przypadku procesów innowacji. Wspólna analiza celu procesu innowacji prowadzi do wymiany doświadczeń i pozwala zweryfikować posiadane zasoby wiedzy, eliminując z nich wiedzę nieaktualną bądź bezużyteczną. Może też być elementem tworzenia przez uzgodnienie nowego spojrzenia na funkcjonowanie firmy, tym samym wpływać na rozwój jej strategii.

Zastosowanie metody QFD prowadzi do łączenia wiedzy z różnych obszarów, co pozwala doskonalić mechanizmy planowania procesów innowacji. Istotny jest także formalny zapis ustaleń i uzgodnień, bez czego nie jest możliwa wieloetapowa analiza zespołowa. Zastosowanie proponowanego rozwiązania umożliwiło praktyczne wykorzystanie wiedzy, będącej zasobem organizacji. We wcześniejszych próbach uzgodnienia zmian w systemie produkcyjnym czasochłonna dyskusja nie prowadziła do sformułowania wniosków w sposób jednoznaczny. Poprzez wykorzystanie diagramu metody QFD osiąga się efekt przekształcenia wiedzy ukrytej w wiedzę jawną, sformalizowaną, możliwą do zapisania w słowach i liczbach. Dzięki temu jest możliwe jej wielokrotne analizowanie i wykorzystywanie. Może być zatem elementem budowy systemu informatycznego wspierającego realizację procesów innowacji.

\section{Podsumowanie i wnioski}

Jakość procesów zarządczych uwarunkowana jest dostępem do informacji i wiedzy oraz poziomem uzgodnień dotyczących wdrażania rozwiązań wynikających z przyjętej strategii prowadzenia działalności biznesowej. W artykule przedstawiono propozycję wykorzystania znanej i szeroko stosowanej metody QFD do ustalenia na poziomie zarządu rodzaju zmian, jakie mają być wprowadzone w systemie produkcyjnym. Jak wskazują Nonaka i Takeuchi (Nonaka, Takeuchi 2000), informacja ujęta jako strumienie wiadomości jest instrumentem budowania i odkrywania wiedzy. Czyli dopiero informacje, którym nadano odpowiednią strukturę, mogą być wykorzystane, ponieważ są interpretowane w konkretnym kontekście. By to osiągnąc $\mathrm{w}$ odniesieniu do planowania celu procesu innowacji, zaproponowano posłużenie się zmodyfikowaną macierzą metody QFD. Najważniejszym efektem, który dzięki temu uzyskano, było systemowe spojrzenie na potrzeby roz- 
wojowe przedsiębiorstwa jako całości. Prowadzi to do podejmowania takich decyzji, które nie tyle usprawniają pojedynczy fragment funkcjonowania przedsiębiorstwa, co niosą za sobą całościowy efekt skorelowany ze strategią firmy. Wadą proponowanego podejścia może być subiektywizm ocen. W zaprezentowanym przykładzie dokonywali jej sami zarządzający. Jednak wspólne dyskusje, które prowadziły do poczynienia tych ustaleń, pokazały, że wykorzystanie proponowanego podejścia może stanowić wygodną platformę komunikacji i wymiany wiedzy pomiędzy ludźmi zajmującymi się na co dzień różnymi obszarami funkcjonowania firmy. Wiedza będąca w dyspozycji grupy osób ma znacznie wyższą wartość niż wiedza pojedynczej osoby, gdyż prowadzi do uzyskania efektu synergii. Trzeba zatem podkreślić, że walorem takiego rozwiązania jest motywowanie do transferu wiedzy i doprowadzenie do konsensusu - jednoznacznych wniosków. Pracochłonność przygotowania macierzy QFD w tym przypadku nie odgrywa istotnej roli, ponieważ decyzje tego typu są stosunkowo rzadko podejmowane. Można zatem ocenić, że wykorzystanie diagramu metody QFD w uzgodnieniu celu procesu innowacji może być skutecznie wykorzystane, zwiększając sprawność zespołowego podejmowania decyzji, które jest regułą w przypadku planowania procesów innowacji.

\section{Literatura}

1. Cohen L. (1995), Quality Function Deployment. How to Make QFD Work for You, Addison Wesley Longman, Reading.

2. Galbraith J. (1977), Organization Design, Addison Wesley, Reading.

3. Jurczyk-Bunkowska M. (2015), Planowanie procesów innowacji: wymagania, ograniczenia oraz model postępowania, [w:] Kamińska A. (red.), Innowacyjność. Uwarunkowania, strategie, wyzwania, Agencja Wydawnicza Placet, Warszawa.

4. Kisielnicki J. (2004), Zarządzanie wiedzq we współczesnych organizacjach, [w:] Łopusiewicz B. (red.), Zarzadzanie wiedza $w$ systemach informacyjnych, Wydawnictwo Akademii Ekonomicznej we Wrocławiu, Wrocław.

5. Kudryavtsev D., Grigoriev L., Koryshev I. (2014), Applying Quality Function Deployment Method for Business Architecture Alignment, [w:] Devos J., Haas de S. (eds.), Proceedings of the 8th European Conference on IS Management and Evaluation (ECIME 2014), Universiteit Gent, Ghent.

6. Mikuła B. (2011), Istota zarządzania wiedza w organizacji, [w:] Potocki A. (red.), Komunikacja $w$ procesach zarządzania wiedza, Fundacja Uniwersytetu Ekonomicznego w Krakowie, Kraków.

7. Nonaka I., Takeuchi H. (2000), Kreowanie wiedzy w organizacji, Poltext, Warszawa.

8. Perechuda K. (2005), Dyfuzja wiedzy w przedsiębiorstwie sieciowym. Wizualizacja i kompozycja, Wydawnictwo Akademii Ekonomicznej we Wrocławiu, Wrocław.

9. Pomykalski A. (2001), Zarządzanie innowacjami, Wydawnictwo Politechniki Łódzkiej, Łódź.

10. Schermerhorn R. (2008), Zarządzanie, PWE, Warszawa.

11. Schroeder R., Ven van de A., Scudder G., Polley D. (1986), Managing Innovation and Change Processes: Findings from the Minnesota Innovation Research Program, "Agribusiness", nr 2/4.

12. Shahin A. (2008), Quality Function Deployment (QFD): A Comprehensive Review, [w:] Rajmanohar T.P. (ed.), Total Quality Management. Contemporary Perspectives and Cases, ICFAI University Press, Andhra Pradesh. 
13. Suttonm R.I., Pleffer J. (2002), Wiedza a działanie. Przeszkody w wykorzystywaniu zasobów wiedzy w organizacji, Oficyna Ekonomiczna, Kraków.

\section{EMPLOYING THE QFD METHOD TO SUPPORT KNOWLEDGE MANAGEMENT IN THE PLANNING OF INNOVATION PROCESSES}

Abstract: The article proposes the use of a QFD matrix diagram to one of the planning
stages of an innovation process. The aim of this approach is to support knowledge
management, to be exact, to codify tacit knowledge. Innovation processes are usually car-
ried out by multidisciplinary teams in which arrangements are often problematic due to
communication difficulties. Based on the example of the choice of innovative solutions in
a production company, the paper shows the extent to which the use of a QFD method
diagram supports sharing knowledge in order to take decisions related to planning the
purpose of an innovation process.

Keywords: innovation management, planning, quality function deployment, knowledge management 